\title{
PERSEPSI APARATUR PEMERINTAH TENTANG KUALIFIKASI PROFESI HUMAS
}

\author{
Kokom Komariah, Aat Ruchiat Nugraha, Susie Perbawasari \\ Program Studi Hubungan Masyarakat \\ Fakultas Ilmu Komunikasi Universitas Padjadjaran \\ Email : kokomkomariah.humas@gmail.com; aatruchiat.nugraha@gmail.com
}

\begin{abstract}
There are still many differences in the views of the public relations profession, namely as a "handyman" read the news, frontline, photographer, maker of the press conference, reception, to the functions of public relations as a strategic planner in the decision-making body or a part of the dominant coalition. Perceptions of a profession that is contained in an organization, it is significant because it may affect how a person appreciate the work or duties, and qualifications of the professional field. This research was conducted in order to reveal the existence of phenomena that occur on the Public Relations profession in the District Government Pangandaran. The method used in the form of quantitative methods and the types of descriptive survey study. The respondents were selected were government officials working in the district administration Pangandaran with data collection is done by means of the distribution of questionnaires, interviews, observation, and literature studies. The results showed that the apparatus of government in the district of Pangandaran has to perceive I interpret the qualifications Public Relations profession is well on aspects of the ability to communicate, ability to organize, ability to get on with people, and imagination. However, in the aspect of personal integrity there that consider a Public Relations officials do not have to come from public relations education / communication and should not be a woman.
\end{abstract}

Keywords: Perception, Public Relations, Competence, and Government Public Relations

\begin{abstract}
ABSTRAK
Masih banyaknya perbedaan pandangan orang terhadap profesi Humas, yaitu sebagai "tukang" baca berita, frontliner, fotografer, pembuat press conference, penerima tamu, sampai kepada fungsi humas sebagai perencana strategis dalam pengambilan keputusan lembaga atau bagian dari koalisi dominan. Persepsi terhadap suatu profesi yang terdapat pada suatu organisasi, menjadi penting karena dapat berakibat pada bagaimana seseorang menghargai pekerjaan atau tugas, dan kualifikasi dari bidang profesi tersebut. Penelitian ini dilakukan dalam rangka mengungkap fenomena yang terjadi terhadap keberadaan profesi Humas di lingkungan pemerintah Kabupaten Pangandaran. Metode penelitian yang digunakan berupa metode kuantitatif dengan jenis studi survei deskriptif. Adapun responden yang terpilih adalah aparat pemerintah yang bekerja di lingkungan pemerintahan kabupaten Pangandaran dengan teknik pengumpulan data dilakukan dengan cara pembagian kuesioner, wawancara, observasi, dan studi literatur. Hasil penelitian menunjukkan bahwa aparat pemerintah di Kabupaten Pangandaran telah mempersepsi/menafsirkan tentang kualifikasi profesi Humas ini dengan baik pada aspek ability to communicate, ability to organize, ability to get on with people, dan
\end{abstract}


imagination. Namun, pada aspek personel integrity masih ada yang menganggap seorang pejabat Humas tidak harus berasal dari pendidikan kehumasan/komunikasi dan tidak harus seorang perempuan.

\section{Kata kunci : Persepsi, Humas, Kompetensi, dan Humas Pemerintah}

\section{PENDAHULUAN}

Setiap kali mendengar tentang Humas, selalu dikaitkan dengan berbagai hal yang telah terstigmakan mengenai profesi Humas. Padahal, profesi Humas memiliki kandungan makna yang positif, netral, bahkan negatif. Bila ditelusuri, mungkin pemaknaan profesi Humas di Indonesia dapat terjadi demikian, seperti kita cermati bersama merupakan hal itu dapat terjadi karena akumulasi dari pesan-pesan yang dilakukan oleh para praktisi kehumasan yang secara tidak sengaja maupun sengaja menyampaikan fungsi dan peran Humas yang dangkal dan hal ini terus dikomunikasikan secara terus menerus kepada publik.

Berdasarkan pendapat kekinian dari para praktisi dan akademisi Public Relations (PR) atau Hubungan Masyarakat (Humas) di dunia, adalah bahwa Public Relations harus diposisikan secara ideal, baik secara fungsi maupun struktur. Posisi ideal dalam konteks ini yaitu berada dalam jajaran top management atau koalisi dominan dari suatu organisasi yang memiliki fungsi sebagai penentu dalam pengambilan keputusan dan mengendalikan organisasi dalam hal informasi. Selanjutnya, dalam hal humas sebagai posisi strategis, petugas humas harus memiliki atau ambil bagian dalam proses perencanaan strategis lembaga, sebagai representasi keberadaan humas dapat memberikan masukan dari publik yang telah diperolehnya untuk disampaikan kepada pimpinan. Dan disisi lian, seorang pejabat humas harus mampu mengelola dan berkoordinasi dengan bagian-bagian lainnya secara kolaboratif dalam menyelesaikan suatu masalah. Jadi, dalam hal ini jabatan humas memeiliki peran ganda yang dapat dijalankan oleh pejabat humas dalam sebuah lembaga pemerintah dan atau swasta, yaitu peran sebagai manajer, dan peran sebagai teknisi. Untuk menghadapi kedua jenis peran tersebut, kiranya humas pemerintah lebih khusus, harus mempunyai kemampuan dalam menguasai seluk beluk bidang pemerintahan atau sektor publik, memiliki kemampuan riset baik untuk memperoleh input dari publik maupun untuk mengevaluasi program-program yang menjadi tanggung jawabnya, memiliki perencanaan, dan memiliki jiwa kepemimpinan.

Seiring dengan tuntutan dari masyarakat yang semakin kritis, dalam melaksanakan kerjanya, bagian humas lembaga pemerintah harus diisi oleh orangorang yang berlatar belakang pendidikan ilmu komunikasi/kehumasan guna memenuhi tugas humas pada level manajemen dan teknis secara profesional. Kedua level tersebut sangat menunjang dalam mengimplementasikan program-program kehumasan yang telah direncanakan dan masuk sebagai bagian dari program keterbukaan informasi publik yang memiliki nilai strategis. 
Di era keterbukaan informasi ini, lembaga pemerintahan memiliki kewajiban untuk dapat menyediakan, mengolah, dan menyampaikan berbagai macam informasi untuk kepentingan publik, maka selayaknya tugas yang dijalankan oleh Humas lembaga pemerintah ini sebenarnya berat dan bahkan sangat menantang dibandingkan dengan peran Humas di sektor swasta atau bisnis.

Pada praktiknya di Indonesia, posisi strategis Humas belum berada pada level koalisi dominan yang sejajar dengan para pimpinan pemegang kebijakan. Menurut hasil penelitian yang dilakukanoleh Elizabeth Goenawan Ananto (dalam BPP Perhumas, 2004:5), ternyata hanya $8 \%$ saja eksekutif Humas yang menjabat sebagai direktur pada sebuah organisasi. Menurut hasil penelitiannya tersebut, apabila eksekutif Humas tidak duduk dalam koalisi dominan, maka kedudukan Humas akan sulit untuk dapat menentukan fungsi Humas secara ideal, betapapun pelaksana Humas berusaha untuk memenuhi tujuan komunikasinya.

Hal ini berarti untuk menilai kemampuan profesional profesi Humas, dapat ditunjukkan oleh pejabat Humas yang telah memenuhi standar-standar kompetensi dan kode etik di bidang kehumasan yang diakui secara nasional yang kemudian diaplikasikan di lembaga atau organisasi dimana ia bekerja. Sesuai pandangan Jefkin (1988), kesuksesan profesi Humas dimulai dari kemampuan berkomunikasi, kemampuan menjalin hubungan yang baik dengan orang lain, kemampuan mengorganisasikan, memiliki jiwa kreatif, integritas, dan penuh dengan imajinasi. Penjelasan Jefkin (1988) mengandung pengertian bahwa profesi Humas yang professional harus memiliki kompetensi-kompetensi yang qualified.

Dalam rangka mengimplementasikan kebaradaan Humas yang professional pada lembaga pemerintahan, Pangandaran sebagai kabupaten baru di Jawa Barat, memiliki potensi tersendiri dalam mengelola pemerintahannya, khususnya dalam implementasi bidang kehumasan, Humas di lingkungan kabupaten Pangandaran masih dikategorikan sangat muda secara administratif dan fungsi. Padahal, secara struktur organisasi di pemerintah kota/kabupaten, saat ini sebenarnya sudah diberikan aturan dalam menyusun struktur organisasi sesuai dengan kebutuhan. Biasanya bagian humas di lingkungan pemerintahan menempati pada bagian sebuah badan atau kantor dengan pejabat yang memiliki eselon lebih tinggi. Akan tetapi, di pemerintah kabupaten Pangandaran, posisi humas ditempatkan pada struktur organisasi dibawah koordinasi sekretariat daerah dan secara structural bertanggungjawab kepada bagian umum, dan namanya sub seksi Humas dan Keprotokoleran. Dengan demikian, posisi profesi Humas secara struktural masih berada di posisi rendah denga fungsi dan kewenangannya belum optimal baik sebagai peran manajer yang memiliki fungsi selaku perencana strategis dan penentu dalam pengambilan keputusan.

Penelitian ini menguraikan tentang persepsi responden mengenai profesi Humas yang professional di kalangan aparatur sipil negara di lingkungan pemerintahan kabupaten Pangandaran. Apabila ditemukan hasil pilihan responden yang tidak sesuai dengan kompetensi yang disyaratkan seorang profesional Humas sesuai pendapat 
Jefkin, peneliti berusaha memberikan solusi yang berdasarkan referensi-referensi yang terkait dengan perkembangan kehumasan.

Berdasarkan latar belakang tersebut, penelitian ini difokuskan pada lima identifikasi masalah persepsi responden terhadap profesi Humas, yaitu Pertama, ability to communicate (kemampuan berkomunikasi) yang dimiliki oleh Humas di lingkungan Pemerintahan Kabupaten Pangandaran. Kedua, ability to get on with people, kemampuan menjalin hubungan baik dengan orang lain. Ketiga, ability to organize, kemampuan mengelola suatu kegiatan kehumasan. Keempat, Personality and Integrity, berkepribadian dan memiliki integritas. Dan Kelima, Creativity and Imagination, memiliki jiwa penuh imajinasi dan kreativitas.

\section{TINJAUAN PUSTAKA}

\section{Persepsi akan Organisasi}

Persepsi dapat didefinisikan sebagai cara organism memberi makna (William W. Wilmot, dalam Mulyana, 2013: 180). Lebih lanjut dijelaskan oleh Mulyana bahwa, proses memberi makna atau penafsiran (interpretasi) adalah inti persepsi, yang identik dengan penyandian-balik (decoding) dalam proses komunikasi. Persepsi menjadi penting pada studi perilaku organisasi, karena perilaku dan persepsi para anggota organisasi akan didasarkan pada pengalaman yang mereka miliki atas organisasi.

Persepsi dan penilaian terhadap tindakan seseorang akan banyak dipengaruhi oleh pengandaian-pengandaian yang kita ambil mengenai keadaan internal orang itu (Rivai, 2003:231). Pendapat yang lain mengatakan bahwa, persepsi manusia terhadap sesorang, objek, atau kejadian berdasarkan pengalaman (dan pembelajaran) masa lalu mereka berkaitan dengan orang, objek atau kejadian serupa (Mulyana, 2013:191).

Mempersepsikan dan menafsirkan apa yang dilakukan orang lain merupakan suatu beban, akibatnya individu sering menggunakan jalan pintas dalam menilai orang lain melalui cara-cara sebagai berikut : Persepsi selektif, yaitu individu melakukan persepsi secara selektif terhadap apa yang disaksikan berdasarkan kepentingan, latar belakang, pengalaman, sikap. Hal ini terjadi karena individu tidak dapat mengasimilasikan semua yang diamati, hal ini karena efek halo, efek kontras, proyeksi, dan berstereotipe yaitu individu menilai seseorang atas dasar persepsinya terhadap kelompok orang tersebut. Persepsi jalan pintas, seringkali terjadi kesalahan (ketidaktepatan) dalam menilai orang lain. Penerapan jalan pintas sering terjadi pada wawancara karyawan, pengharapan kinerja, evaluasi kinerja, upaya karayawan, dan kesetiaan karyawan (Rivai, 2003:233-234).

Persepsi akan organisasi dimaksudkan sebagai persepsi atas unsur-unsur organisasi dan pengaruh unsur-unsur tersebut terhadap komunikasi. Unsur-unsur organisasi yang dimaksud adalah : 1) anggota organisasi; orang-orang yang melaksanakan pekerjaan organisasi, 2) Pekerjaan dalam organisasi; pekerjaan para anggota organisasi terdiri dari tugas-tugas formal dan informal, 3) praktik-praktik 
pengelolaan; bagaimana menyelesaikan pekerjaan melalui usaha orang lainnya, misalnya bagaimana manajer membuat keputusan mengenai bagaimana orang-orang lainnya/bawahannya menggunakan sumber daya yang diperlukan untuk melaksanakan pekerjaan mereka, 4) struktur organisasi; hal ini merujuk kepada hubungan antara tugas-tugas yang dilaksanakan oleh anggota-anggota organisasi. Dan terdapat tiga variabel kunci : kompleksitas, formalitas, dan sentralisasi, 5) Pedoman Organisasi; adalah serangkaian pernyataan yang mempengaruhi, mengendalikan, dan memberi arahan bagi anggota organisasi dalam mengambil keputusan dan tindakan (Faules \& Face, 1998:151-153). Pengaruh ini didefinisikan, disepakati, dikembangkan dan dikokohkan secara berkesinambungan melalui interaksi dengan anggota organisasi lainnya. "Pengaruh ini menghasilkan pedoman bagi keputusan-keputusan dan tindakantindakan individu, dan mempengaruhi pesan-pesan mengenai organisasi" (Pace \& Faules, 1998: 149).

\section{Public Relations Pemerintah}

PR/humas di lembaga pemerintahan dibentuk tentunya untuk mempublikasikan atau mempromosikan kebijakan-kebijakan pemerintah, baik di tingkat pusat maupun lokal/daerah. Frida Kusumastuti (2002) berpendapat bahwa humas pemerintah harus memberi informasi secara teratur tentang kebijakan, rencana-rencana, serta hasil-hasil kerja institusi serta memberi pengertian kepada masyarakat tentang peraturan dan perundang-undangan dan segala sesuatunya yang berpengaruh terhadap kehidupan bermasyarakat. Selain keluar, humas pemerintahan dan politik juga harus memungkinkan untuk memberi masukan dan saran bagi para pejabat tentang segala informasi yang diperlukan dan reaksi atau kemungkinan reaksi masyarakat akan kebijakan institusi, baik yang sedang dilaksasnakan, akan dilaksanakan, ataupun yang sedang diusulkan (Kusumastuti, 2002:37). Menurut Sam Black (dalam Effendy, 1992:40), ada empat tujuan utama humas pemerintahan daerah, yakni :

1) Memelihara penduduk agar tahu jelas mengenai kebijaksanaan lembaga beserta kegiatannya sehari-hari;

2) Memberi kesempatan kepada mereka untuk menyatakan pandangannya mengenai proyek baru yang penting sebelum lembaga mengambil keputusan;

3) Memberikan penerangan kepada penduduk mengenai cara pelaksanaan sistem pemerintahan daerah dan mengenai hak-hak dan tanggung jawab mereka;

4) Mengembangkan rasa bangga sebagai warga negara.

$\mathrm{PR} /$ humas pada lembaga pemerintah harus dimiliki dua peran, yaitu pertama peran manajer, dan kedua peran teknisi. Kemampuan untuk kedua peran tersebut, I Gusti Ngurah Putra (2004) berpendapat, "Kemampuan yang harus dimiliki oleh seorang manajer public relations antara lain harus menguasai seluk beluk bidang pemerintahan atau sektor publik, memiliki kemampuan riset baik untuk memperoleh input dari publik maupun untuk mengevaluasi program public relations yang menjadi 
tanggung jawabnya, memiliki perencanaan, memimpin bagian public relations". Dan bagian public relations lembaga pemerintah juga harus diisi dengan tenaga teknisi, yang bertugas untuk mengimplementasikan program-program public relations yang sudah dirancang oleh manajer public relations" (Putra, 2004:121-122).

\section{Public Relations yang strategis}

Menurut James E. Grunig yang sitir oleh Elizabeth Goenawan Ananto (2004), mengemukakan prinsip dasar public relations yang strategis :

1) Manajemen komunikasi antara organisasi dengan publiknya;

2) Suatu profesi yang berlandaskan pengetahuan ilmiah;

3) Fungsi manajemen selain dari fungsi teknis komunikasi ilmiah;

4) Konseling strategik dan bukan publikasi semata.

(dalam BPP Perhumas, 2004:2)

Pada kebanyakan organisasi atau perusahaan yang ada di Indonesia hanya $8 \%$ saja eksekutif PR yang menduduki sebagai direktur (Ananto, dalam BPP Perhumas 2004:6). Melihat kondisi tersebut, biasanya praktisi PR tidak mempunyai kebebasan untuk bertindak sebagai seorang profesional, karena mereka belum mempunyai wewenang untuk memasukkan unsur tanggungjawawab sosial, pemahaman publik atau komunikasi dua arah. Lebih jauh lagi, jika tujuan PR dimasukkan menjadi tujuan organisasi, eksekutif PR duduk sebagai koalisi dominan (Ananto, dalam BPP Perhumas 2004:3). Jadi jika eksekutif PR tidak duduk dalam koalisi dominan, akan sulit untuk menentukan fungsi PR, betapa pun pelaksana PR berusaha untuk memenuhi tujuan komunikasinya.

\section{Kualifikasi Profesi Public Relations (Humas)}

Menurut Jefkins (1988) terdapat lima persyaratan mendasar bagi seorang yang berprofesi sebagai Public Relations (humas) :

1) Ability to communicate (kemampuan berkomunikasi)

2) Ability to organize (kemampuan mengorganisasikan)

3) Ability to get on with people (kemampuan bergaul/membina relasi)

4) Personal Integrity (berkepribadian utuh/jujur)

5) Imagination (memiliki imajinasi yang kuat)

(dalam Soemirat dan Ardianto, 2002:159)

Lebih jauh, Soemirat dan Ardianto (2002) menjabarkan kelima kualifikasi profesi Public Relations (humas) sebagai berikut :

1) Ability to communicate (kemampuan berkomunikasi)

Kemampuan berkomunikasi seorang PR mencakup lisan maupun tertulis. Komunikasi lisan seperti public speaking atau presentasi, sedangkan penulisan press release dan mengelola media atau majalah adalah kemampuan komunikasi tertulis. 
Menurut Soemirat dan Ardianto (2002:160), "Dalam aspek keilmuan, komunikasi adalah induk ilmu dari bidang public relations (PR) sedangkan dalam dunia PR, komunikasi merupakan tulang punggung (backbone) PR dalam melakukan berbagai programnya".

Dalam bekerja PR (humas) berhadapan dengan orang dengan berbagai karakter, oleh karena itu Jefkins berpendapat bahwa, "PR harus mampu dan mau berusaha memahami, serta terkadang berusaha untuk bersikap setoleran mungkin kepada setiap orang yang dihadapinya tanpa harus menjadi penakut atau penjilat (dalam Soemirat dan Ardianto, 2002:159)

\section{2) Ability to organize (kemampuan mengorganisasikan)}

Kemampuan mengorgnisasikan diartikan sebagai kemampuan manajerial. Dalam mengelola program PR mulai dari fact finding, planning, communicating dan evaluating.

Menurut Soemirat dan Ardianto, "Kemampuan mengorganisasikan membuat seorang PR selalu berfikir, membuat rencana, membuat laporan, dan mengevaluasi setiap program yang telah dijalankannya. Dalam melakukan aspek manajerial ini selalu didukung berpikir jernih dan bersikap positif ketika menghadapi permasalahan manajemen PR" (Soemirat dan Ardianto, 2002:160)

3) Ability to get on with people (kemampuan bergaul/membina relasi)

Maksud dari kemampuan ini adalah kemampuan PR menciptakan jejaring (networking) dengan berbagai pihak, berbagai unsur publik yang berkaitan dengan organisasi atau perusahaan, sehingga para relasi dapat mendukung berbagai program PR. Soemirat dan Ardianto berpendapat, "Dalam membina relasi harus terjalin take and give antara keduanya dan terjadi hubungan yang sinergi antara PR dan berbagai unsur publik ini, yang tetap berlandaskan integritas profesi" (2002:160). Kemampuan ini tentunya memerlukan keluwesan dalam bergaul dan selalu mencerminkan simpatik orang lain, sehingga orang lin itu sangat well come ketika dihubungi maupun diajak kerja sama.

4) Personal Integrity (berkepribadian utuh/jujur)

Kejujuran adalah mata uang yang berlaku dimana-mana, di dalam setiap aspek kehidupan. "Kejujuran harus tetap melandasi seseorang yang menjadi profesi apa pun, termasuk public relations (humas), karena aspek ini yang dapat membentuk kredibilitas (kepercayaan) orang lain terhadap petugas PR, maupun terhadap perusahaannya. Soemirat jurdan Ardianto berpendapat, "Kejujuran ini pula yang dapat membentuk kepribadian yang utuh bagi seorang PRO” (2002:161).

5) Imagination (memiliki majinasi yang kuat)

"Profesi PR haruslah seseorang yang penuh dengan gagasan atau ide-ide, mampu memecahkan problem yang dihadapi, mampu menyusun rencana yang orisinal dan 
dapat mengembangkan imajinasi untuk melahirkan kreativitas-kreativitas kerjanya" (Soemirat dan Ardianto, 2002:162)

Kreativitas ini bisa mencakup berbagai kegiatan seperti mengelola berbagai special event PR (pameran, workshop, seminar, press conference dan lainnya), pembuatan house journal (media penerbitan PR), krisis manajemen dan lain sebagainya. Semua itu diperlukan pengamatan yang tajam, persepsi yang baik serta pemikiran yang orisinal dan perhatian penuh dalam mencari peluang-peluang. Semua harus dalam kaitan pola komunikasi (Jefkins, dalam Soemirat dan Ardianto, 2002:162)

Secara ringkas Frida Kusumastuti (2002) menggambarkan profil petugas humas dan kualifikasi yang harus dimilikinya sebagai berikut : "Petugas humas haruslah orang yang cukup trampil, khususnya di bidang penulisan (writing), speaking, mendengarkan, membaca, dan menggunakan alat-alat komunikasi lainnya. PRO harus memiliki pengetahuan yang mendalam tentang berbagai macam media dan memahami proses manajemen. PRO harus memiliki kemampuan dalam memecahkan suatu masalah (problem solver), dalam mengambil keputusan, mengelola opini publik, mengevaluasi kecenderungan perilaku dan respon publik. PRO harus memiliki selera dan kepribadian yang baik tentang etika, simpati, dan empati, kepemimpinan,semangat/etos, kreativitas, dan imajinasi, kematangan/stabilitas kepribadian serta integritas pribadi" (Kusumastuti, 2002:59)

\section{METODE PENELITIAN}

Metode penelitian yang digunakan dalam penelitian ini adalah survei deskriptif, dengan instrumen utama penelitian adalah kuesioner. Jenis penelitian deskriptif bertujuan membuat deskripsi secara sistematis, faktual, dan akurat tentang fakta-fakta dan sifat-sifat populasi atau objek tertentu. Periset sudah mempunyai konsep (biasanya satu konsep) dan kerangka konseptual (Kriyantono, 2007:68). Metode survei dengan teknik analisis data deskriptif, yaitu melakukan pengukuran yang cermat terhadap fenomena social tertentu. Peneliti mengembangkan konsep dan menghimpun fakta, tetapi tidak melakukan pengujian hipotesa (Singarimbun dan Effendi, 1995:4-5).

Populasi penelitian ini adalah aparatur sipil negara yang terdaftar dalam pelatihan kehumasan tingkat kabupaten Pangandaran. Adapun teknik sampel dalam penelitian ini adalah sensus. Karena itu semua peserta yang ada di pelatihan kehumasan tersebut menjadi sampel dalam penelitian ini.

Data penelitian ini berupa data primer dan data sekunder. Data primer berupa kuisioner yang berisikan pertanyaan seputar kualifikasi seorang Humas yang professional yang dibagikan kepada peserta pelatihan kehumasan bagi paratur sipil negara tingkat kabupaten Pangandaran. Sedangkan data sekunder diperoleh dari wawancara kepada kepala bagian Humas Setda Kabupaten Pangandaran, observasi di lapangan, serta studi kepustakaan berupa teori-teori yang relevan, dan hasil-hasil penelitian sejenis. 


\section{HASIL PENELITIAN DAN PEMBAHASAN}

Sebelum penulis melakukan pembahasan pada faktor-faktor yang menjadi kajian penelitian. Penting utnuk dipaparkan terlebih dahulu kondisi data responden karena menurut penulis frame of reference dari responden ini akan mempengaruhi cara responden memberi makna. Pada bagian ini diuraikan hasil penelitian yang berkaitan dengan unsur-unsur data penelitian mengenai persepsi apartur sipil negara terhadap profesi Humas.

Berdasarkan data responden, menunjukkan profil responden yaitu aparatur sipil negara mayoritas $82,75 \%$ adalah laki-laki, dan hanya sebagian kecil $(17,25 \%)$ responden berjenis kelamin perempuan. Kebanyakan responden menunjukkan 86, $12 \%$ mempunyai pendidikan tinggi, diantaranya $27,59 \%$ sudah S2 atau magister. Usia responden terbanyak $55,17 \%$ adalah usia dewasa madya yaitu 50th-53th, dan hanya sebesar $6,9 \%$ saja yang berusia sekitar 20th-30th. Sedangkan dalam hal lamanya bekerja responden menunjukkan angka 44,83\% sudah bekerja diantara 20th-30th, artinya responden sudah mempunyai banyak pengalaman kerja.

Adapun data penelitian tergambarkan sebagai berikut :

1. Persepsi aparatur pemerintah tentang kualifikasi profesi kehumasan pada aspek ability to communicate (kemampuan berkomunikasi) menghasilkan data sebagai berikut :

Tabel 1.

Persepsi Responden pada Aspek Ability to Communicate

\begin{tabular}{|c|c|c|c|c|c|c|}
\hline \multirow{3}{*}{$\begin{array}{c}\text { Ability communicate } \\
\text { (Kemampuan Berkomunikasi) }\end{array}$} & \multicolumn{6}{|c|}{$\begin{array}{c}\text { Jawaban } \\
(\mathbf{n}=29)\end{array}$} \\
\hline & \multicolumn{2}{|c|}{ Setuju } & \multicolumn{2}{|c|}{$\begin{array}{c}\text { Ragu/ } \\
\text { tidak } \\
\text { tahu }\end{array}$} & \multicolumn{2}{|c|}{$\begin{array}{l}\text { Tidak } \\
\text { setuju }\end{array}$} \\
\hline & $\mathbf{f}$ & $\%$ & $\mathbf{f}$ & $\%$ & $\mathbf{f}$ & $\%$ \\
\hline $\begin{array}{l}\text { a. Menulis yang baik dalam rangka } \\
\text { menciptakan citra positif lembaga }\end{array}$ & 26 & 89,65 & 1 & 3,45 & 2 & 6,90 \\
\hline $\begin{array}{l}\text { b. Berbicara di depan umum dalam } \\
\text { menyampaikan menjelaskan informasi } \\
\text { kepada publiknya }\end{array}$ & 28 & 96,55 & 0 & 0 & 1 & 3,45 \\
\hline c. Berbahasa asing (Inggris) & 23 & 79,31 & 2 & 6,90 & 4 & 13,79 \\
\hline $\begin{array}{l}\text { d. Membaca berita/informasi di berbagai } \\
\text { media cetak dan elektronik }\end{array}$ & 29 & 100 & 0 & 0 & 0 & 0 \\
\hline e. Menjadi pendengar yang baik & 25 & 86,20 & 2 & 6,90 & 2 & 6,90 \\
\hline $\begin{array}{l}\text { f. Mengaplikasikan teknologi komunikasi } \\
\text { dan informasi dalam penyampaian pesan } \\
\text { lembaga dimedia sosial }\end{array}$ & 25 & 86,20 & 2 & 6,90 & 2 & 6,90 \\
\hline
\end{tabular}

Persepsi responden mengenai kualifikasi profesi kehumasan aspek ability to communicate (kemampuan berkomunikasi), ternyata seluruh (100\%) responden setuju bahwa kemampuan membaca dan melek terhadap isi informasi yang ada di media menjadi syarat penting bagi profesi Humas. Dalam hal ini memang profil humas pemerintah sering dimaknai sebagai staf dokumentasi dan publikasi, yang kerjanya 
membaca berbagai media surat kabar. Sementara itu, sebagian besar responden menyatakan setuju bahwa profesi Humas harus memiliki kemampuan berkomunikasi baik lisan maupun tulisan, berkomunikasi langsung tatap muka mau pun bermedia (penggunaan alat-alat/media komunikasi). Selain itu, harus dapat menjadi seorang pendengar yang baik bagi publiknya untuk dapat menyerap saran, kritik, dan isu yang berkembang di masyarakat yang kemudian dikomunikasikan secara dua arah dan timbal balik. Menurut Abidin (2016), ciri spesifik komunikasi publik adalah perhatian penting pada konteks public affairs. Artinya, setiap rencana dan aktivitas dalam komunikasi publik harus dapat didayagunakan untuk memecahkan masalah sosial kemasyarakatan, yang sebagian besar kebijakannya dipegang oleh pemerintah (2016:10). Karenanya, perlu diingat bahwa seorang pejabat humas adalah seorang profesional atau komunikator profesional yang diangkat oleh lembaga pemerintah dengan tugas melayani informasi kebijakan publik dan pelayanan kepada publik.

Dengan adanya perkembangan globalisasi yang semakin kompetitif ini, kemampuan berbahasa Asing, khususnya Bahasa Inggris menjadi kewajiban atau syarat mutlak seorang Humas yang profesional, karena jaringan komunikasi yang terbentuk sudah tidak terbatas lagi dan dapat menjangkau ke pelosok dunia. Sesuai dengan apa yang disampaikan oleh Tondowidjojo (2002:13) yang menyatakan bahwa mengusahakan suatu komunikasi yang baik dalam suatu organisasi merupakan suatu hal yang penting, dimana kegiatan komunikasi Humas yang tertulis dan lisan bersifat receptive (yang menerima seperti mendengar, membaca, dan menerima informasi) dan productive (yang mengirim seperti berbicara, menulis, dan memberikan informasi). Sehingga Humas yang professional pada level manajemen mampu membagi waktu untuk kegiatan komunikasinya sebesar 10\% membaca, 15\% menulis, $20 \%$ berbicara, $30 \%$ mendengarkan, dan $25 \%$ kegiatan lainnya. Jadi, semakin tinggi tingkat manajemen, maka kegiatan komunikasi makin mendekati $100 \%$.

Humas yang profesional di lingkungan pemerintahan harus bisa memiliki kemampuan protokoler. Hal demikian juga terjadi pada Jabatan Humas di pemerintah kabupaten Pangandaran yang mendapat tugas untuk menjadi protokolernya kegiatankegiatan yang menyangkut urusan pemerintahan dengan publiknya. Protokoler ini bagian dari kegiatan komunikasi organisasi yang merepresentasikan kebijakan pimpinan yang perlu terus dikomunikasikan secara formal lisan dan bermedia (Tondowidjojo, 2002:21). Maka, kemampuan Humas yang berperan sebagai protokoler harus dibekali dengan kemampuan teknis lainnya seperti presenter, keprotokolan, master of ceremony (MC), table manner, dan hospitality.

2. Persepsi aparatur pemerintah tentang kualifikasi profesi kehumasan pada aspek ability to organize (kemampuan manajerial) menghasilkan data sebagai berikut : 
Tabel 2.

Persepsi Responden pada Aspek Ability to Organize

\begin{tabular}{|c|c|c|c|c|c|c|}
\hline \multirow{3}{*}{$\begin{array}{c}\text { Ability to Organize } \\
\text { (memiliki kemampuan manajerial) }\end{array}$} & \multicolumn{6}{|c|}{$\begin{array}{c}\text { Jawaban } \\
(\mathbf{n}=29)\end{array}$} \\
\hline & \multicolumn{2}{|c|}{ Setuju } & \multicolumn{2}{|c|}{$\begin{array}{c}\text { Ragu2/ } \\
\text { tidak } \\
\text { tahu }\end{array}$} & \multicolumn{2}{|c|}{$\begin{array}{l}\text { Tidak } \\
\text { setuju }\end{array}$} \\
\hline & $\mathbf{f}$ & $\%$ & $\mathbf{F}$ & $\%$ & $\mathbf{f}$ & $\%$ \\
\hline a. Mengelola suatu kegiatan/event & 27 & 93,10 & 1 & 3,45 & 1 & 3,45 \\
\hline b. Menyelenggarkan kampanye & 27 & 93,10 & 1 & 3,45 & 0 & 0 \\
\hline
\end{tabular}

Humas merupakan kegiatan yang dikembangkan selaras dengan budaya organisasi. Yang di mana budaya organisasi tersebut harus dikomunikasikan ke publik internal dan eksternal guna memperoleh kesan yang positif dari publiknya. Pengkomunikasian tersebut perlu diorganisasikan sehingga dibutuhkan kemampuan manajerial seorang Humas yang memiliki bakat dan mampu mengatur orang lain guna mencapai tujuan organisasi (Tondowidjojo, 2002:47). Oleh karena itu, sudah tidak diragukan lagi, bahwa profesi Humas itu identik dengan kegiatan program, event dan kampanye. Terbukti dari pendapat hampir seluruh responden menafsirkan profesi Humas bidang kerjanya "mengurusi" kegiatan-kegiatan yang bersifat publisitas. Sebenarnya event dan kampanye ini bagian dari kegiatan Humas, hanya kalau event ditujukan untuk satu atau beberapa publik terbatas dan dalam waktu yang terbatas. Sementara kampanye, tidak mempunyai waktu yang terbatas, dan terdiri dari berbagai event yang dilakukan secara berkesinambungan.

Dalam pengelolaan kegiatan kehumasan seperti event dan atau menyelenggarakan kampanye membutuhkan kemampuan manajerial, "Kemampuan mengorganisasikan membuat seorang Humas selalu berfikir, membuat rencana, membuat laporan, dan mengevaluasi setiap program yang telah dijalankannya. Dalam melakukan aspek manajerial ini perlu didukung berpikir jernih dan bersikap positif ketika menghadapi permasalahan manajemen Humas" (Soemirat dan Ardianto, 2002:160). Dengan demikian seorang Humas itu harus memiliki jiwa kepemimpinan untuk dapat menggerakkan orang-orang dalam mengelola sebuah kegiatan kehumasan yang bertujuan untuk image building suatu lembaga.

3. Persepsi aparatur pemerintah tentang kualifikasi profesi kehumasan, aspek ability to get on with people (kemampuan bergaul/membina relasi) menghasilkan data sebagai berikut : 
Tabel 3.

Persepsi Responden pada Aspek Ability to get on with People

\begin{tabular}{|c|c|c|c|c|c|c|}
\hline \multirow{3}{*}{$\begin{array}{l}\text { Ability to get on with People } \\
\text { (kemampuan bergaul/membina relasi) }\end{array}$} & \multicolumn{6}{|c|}{$\begin{array}{c}\text { Jawaban } \\
(\mathbf{n}=\mathbf{2 9})\end{array}$} \\
\hline & \multicolumn{2}{|c|}{ Setuju } & \multicolumn{2}{|c|}{$\begin{array}{c}\text { Ragu2/ } \\
\text { tidak tahu }\end{array}$} & \multicolumn{2}{|c|}{$\begin{array}{l}\text { Tidak } \\
\text { setuju }\end{array}$} \\
\hline & f & $\%$ & $\mathbf{f}$ & $\%$ & f & $\%$ \\
\hline $\begin{array}{l}\text { a. Menjalin hubungan baik } \\
\text { internal. Dengan pimpinan } \\
\text { pemberi sebagai } \\
\text { pengambilan kebijakan suatu lembaga } \\
\text { dan karyawan lain }\end{array}$ & 28 & 96,55 & 1 & 3,45 & 0 & 0 \\
\hline $\begin{array}{l}\text { b. Menjalin hubungan baik dengan } \\
\text { masyarakat sekitar dalam menjaring } \\
\text { aspirasi rakyat }\end{array}$ & 26 & 89,65 & 1 & 3,45 & 2 & 6,90 \\
\hline $\begin{array}{l}\text { c. Menjalin hubungan baik dengan pihak } \\
\text { wartawan/jurnalis dalam upaya } \\
\text { mempublikasi kampanye lembaga }\end{array}$ & 26 & 89,65 & 3 & 10,35 & 0 & 0 \\
\hline
\end{tabular}

Hampir seluruh responden (lebih dari 90\%) meyakini bahwa profesi humas harus pandai bergaul atau membina relasi dengan publik internal seperti dengan pimpinan, karyawan, dan publik eksternal seperti dengan masyarakat dan wartawan/media. Secara umum ability to get on with people dalam konteks humas pemerintahan tersirat pada pendapat Ardianto (2011) sebagai berikut : "Seorang pejabat PR profesional adalah perantara atau jembatan antara lembaga pemerintahan dan rakyat atau masyarakat, baik ke dalam maupun ke luar. Ia harus mampu menjelaskan rencana kebijakan publik dan pelayanan publik, serta ia pun harus mampu mengetahui keinginan dan kepentingan rakyat atau masyarakat, yang kemudian akan ia sampaikan kepada pimpinan puncak sebagai masukan bagi pembuatan kebijakan publik dan pelayanan publik" (Ardianto, 2011:141).

Dalam hal hubungan baik dengan pimpinan/atasan, posisi bagian humas pemkab Pangandaran ditempatkan di level seksi, akan tetapi meskipun begitu humas mempunyai previlage bisa langsung tembus ke puncak pimpinan. Ada pun tentang hubungan dengan karyawan lain (employee relations) sering kali diabaikan karena menganggap itu adalah bagian dari tugas kepegawaian/personalia. Padahal ada perbedaan pandangan antara bagian personalia dengan PR/humas ketika memandang karyawan, yaitu bagian personalia memandang karyawan sebagai 'alat' lembaga yang sudah diberi gaji sehingga tidak diperlukan treatmen lagi.

Lembaga pemerintah sebagai lembaga pelayanan publik/masyarakat, memfungsikan humas di berbagai lini seperti di pemkab, di dinas, di kecamatan dsb. Masalah pelayanan publik pada lembaga pemerintah ini masih perlu penanganan yang serius terkait dengan budaya pelayanan yang ditampilkan oleh instansi. Sebagaimana dipaparkan oleh Saleh bahwa, 1) Masih kuatnya budaya 'dilayani' daripada budaya 
melayani, disebabkan mereka menganggap bahwa masyarakatlah yang membutuhkan kehadiran mereka dan juga karena monopoli pelayanan yaitu hanya lembaga pemerintah yang menyediakan layanan tersebut, misalnya membuat KTP. Sehingga masyarakat terpaksa bertindak sebagaimana yang diinginkan oleh petugas. 2) Budaya pelayanan yang ditampilkan masih cenderung birokratik. 3) Persepsi publik untuk mendapatkan pelayanan yang baik dan cepat harus melalui beragam jalur pintas (Saleh : 2010:14).

Untuk menjadi pelayan publik (public service) tentunya harus memberikan pelayanan secara prima (service excellent). Oleh karena itu harus ada perubahan mindset, sebagaimana dianjurkan oleh Saleh, yaitu diantaranya : 1) Mengerti orang lain terlebih dahulu sebelum ingin dimengerti, 2) Menghargai orang lain adalah bagian pengabdian sebagaimana diri anda juga ingin dihargai, 3) Lakukanlah empati yang sangat dalam pada orang lain dan membangun sinergi dengannya, dan 4) Kalau diri kita butuh dilayani dengan cara terbaik, maka orang lain pun juga demikian (Saleh, 2010:17-18).

Perubahan mindset ini tentunya harus di semua lini/kantor yang menjalankan fungsi humas (pemkab, dinas, kecamatan), setiap petugasnya didorong untuk melayani dengan tulus dan dengan penuh kesadaran serta niat yang mulia untuk membantu orang lain dan menjadikan aktivitas itu sebagai bagian dari ibadah. Hubungan baik dengan media, dalam hal ini wartawan/jurnalis merupakan faktor penting dalam pelaksanaan program PR/humas, karena dalam usaha mendapatkan perhatian, kesadaran, dan dukungan dari publik sasaran. Media berfungsi untuk menyebarluaskan, dan mensosialisasikan kepada masyarakat luas. Dalam mengelola hubungan dengan media, prioritas pertama adalah kesediaan humas untuk dapat dihubungi kapan saja, nomornomor kontak perlu disebarkan untuk diketahui media, dan harus disediakan pelayanan setiap waktu. Faktot-faktor vital lainnya dalam mengelola hubungan dengan media, terdiri dari :

1. memelihara naskah-naskah menyangkut posisi perusahaan;

2. siapkan arahan pertanyaan dan jawaban pribadi;

3. hindari jargon dan klaim berlebihan;

4. pengumuman berita yang faktual dan ringkas;

5. siapa? Apa? bagaimana/ kapan? Di mana? Mengapa?;

6. Jangan pernah 'off the record';

7. Tanggapi panggilan media sesegera mungkin;

8. Buat catatan untuk semua panggilan media;

9. Berikan akses ke manajemen puncak bila diperlukan;

10. Pahami media yang berbeda.

(Beard, 2004:123-124)

Dengan demikian, kegiatan PR/humas di dunia pemerintahan harus benar-benar untuk kepentingan rakyat atau publik sehingga seorng pejabat PR harus mampu menciptakan, membina, serta memelihara hubungan ke dalam (pimpinan dan karyawan) dan ke luar (masyarakat, media atau wartawan). 
4. Persepsi aparatur pemerintah akan kualifikasi profesi kehumasan, aspek personal integrity (berkepribadian utuh/jujur) menghasilkan data sebagai berikut :

Tabel 4.

Persepsi Responden pada Aspek Personal and Integrity

\begin{tabular}{|c|c|c|c|c|c|c|}
\hline \multirow{3}{*}{$\begin{array}{c}\text { Personal and Integrity } \\
\text { (Berkepribadian Utuh dan Jujur) }\end{array}$} & \multicolumn{6}{|c|}{$\begin{array}{c}\text { Jawaban } \\
(\mathbf{n}=\mathbf{2 9})\end{array}$} \\
\hline & \multicolumn{2}{|c|}{ Setuju } & \multicolumn{2}{|c|}{$\begin{array}{c}\text { Ragu2/ } \\
\text { tidak tahu }\end{array}$} & \multicolumn{2}{|c|}{$\begin{array}{l}\text { Tidak } \\
\text { setuju }\end{array}$} \\
\hline & $\mathbf{f}$ & $\%$ & $\mathbf{f}$ & $\%$ & $\mathbf{f}$ & $\%$ \\
\hline $\begin{array}{l}\text { a. Memiliki kepribadian/watak yang baik } \\
\text { di saat menjalankan tugas dan } \\
\text { fungsinya }\end{array}$ & 29 & 100 & 0 & 0 & 0 & 0 \\
\hline $\begin{array}{l}\text { b. Memiliki pendidikan formal } \\
\text { humas/komunikasi }\end{array}$ & 17 & 58,62 & 8 & 27,59 & 4 & 13,79 \\
\hline c. Berpenampilan menarik secara fisik & 14 & 48,28 & 6 & 20,69 & 9 & 31,03 \\
\hline d. Harus dijabat seorang perempuan & 1 & 3,45 & 12 & 41,38 & 16 & 55,17 \\
\hline
\end{tabular}

Dari tabel 4 tersebut, menunjukkan seluruh responden (100\%) dalam hal kepribadian/watak berpendapat setuju bahwa seorang profesi humas harus mempunyai watak yang baik, jujur dalam menjalankan tugas. Memang semestinya faktor kepribadian ini dalam segala aspek kehidupan patut dimiliki oleh semua orang pada berbagai profesi. Menurut Ardianto (2011), "Dalam menjalankan tugasnya sebagai 'jembatan', pejabat humas harus memiliki moral dan tingkah laku yang baik agar ia dapat memperoleh kredibilitas dan menjadi teladan bagi publik. Hal ini sangat penting dalam upaya bekerja dan bertindak tegas, cermat, dan akurat dalam menjalankan tugas sebagai PR di dunia pemerintahan" (Ardianto, 2011:242).

Sementara itu pada aspek pendidikan formal yang harus humas/komunikasi serta padahal penampilan fisik harus menarik, responden masih ada yang ragu-ragu bahkan ada yang tidak setuju. Dan setengah dari reponden menyatakan tidak setuju kalau profesi humas harus dijabat seorang perempuan.

Kiat untuk menjadi PR profesional, menurut Ruslan yang dikutip oleh Ardianto (2011:176-177), diantaranya harus memiliki skill atau kemampuan, pengetahuan tinggi dari orang umum lainnya, apakah diperoleh dari hasil pendidikan atau pelatihan yang diperolehnya, dan ditambah dengan pengalaman selama bertahun-tahun yang telah ditempuhnya sebagai profesional. Serta kemampuan untuk berperilaku etis, yaitu memiliki perilaku, sikap, etika moral dan tata krama (etiket) yang baik (good moral and good manner) dalam bergaul atau berhubungan dengan pihak lain dan (social contact). Termasuk memperhatikan hak-hak pihak lain dan dengan menghormati pendapat atau menghargai martabat orang lain. 
5. Persepsi aparatur pemerintah tentang kualifikasi profesi kehumasan, aspek Imagination (Imajinasi yang Kuat) menghasilkan data sebagai berikut :

\section{Tabel 5.}

Persepsi Responden pada Aspek Imagination

\begin{tabular}{|c|c|c|c|c|c|c|}
\hline \multirow{3}{*}{$\begin{array}{c}\text { Imajination } \\
\text { (Memiliki Imajinasi yang Kuat) }\end{array}$} & \multicolumn{6}{|c|}{$\begin{array}{c}\text { Jawaban } \\
(n=29)\end{array}$} \\
\hline & \multicolumn{2}{|c|}{ Setuju } & \multicolumn{2}{|c|}{$\begin{array}{c}\text { Ragu2/ } \\
\text { tidak } \\
\text { tahu }\end{array}$} & \multicolumn{2}{|c|}{$\begin{array}{l}\text { Tidak } \\
\text { setuju }\end{array}$} \\
\hline & $\mathbf{f}$ & $\%$ & $\mathbf{f}$ & $\%$ & f & $\%$ \\
\hline a. Memiliki banyak ide dan kreatif & 27 & 93,10 & 1 & 3,45 & 1 & 3,45 \\
\hline $\begin{array}{l}\text { b. Membuat opini publik yang favorable } \\
\text { bagi lembaga }\end{array}$ & 28 & 96,55 & 0 & 0 & 1 & 3,45 \\
\hline
\end{tabular}

Mayoritas responden sependapat kalau profesi humas itu harus memiliki imajinasi, maksudnya profesi humas haruslah seseorang yang penuh dengan gagasan atau ide-ide dan rencana yang orisinal, mampu memecahkan masalah yang dihadapi, dan dapat mengembangkan imajinasi untuk melahirkan kreativitas-kreativitas kerja dan kinerjanya. Sering kali lembaga atau organisasi menghadapi masalah atau krisis, sehingga humas harus memiliki kemampuan dalam memecahkan suatu masalah (problem solver), dalam mengambil keputusan, mengelola opini publik, mengevaluasi kecenderungan perilaku dan respon publik.

Kreativitas tugas Humas ditampilkan dalam cara berpikir yang holistik dan sesuai dengan proses serta aspek manajemen Humas. Menurut Ardianto (2011:211) agar proses dan aspek manajemen Humas dalam sebuah organisasi dapat optimal dan mencapai sasaran yang telah ditentukan, yakni tercapinya pembentukan citra yang positif dan reputasi yang baik, tentunya harus ditunjang oleh fungsi dan struktur Humas yang ada dalam jajaran top management. Sehingga kreativitas seorang Humas yang profesional dapat mengikuti langkah-langkah manajemen "ala" Pertama, menurut Cutlip, Center dan Broom yang terdiri atas defining public relations problems, planning and programming, taking action and communicating, dan evaluating the program. Kedua, menurut Frans Jefkins yang terdiri atas pengenalan situasi, penetapan tujuan, definisi khalayak, pemilihan media dan teknik-teknik Humas, perencanaan anggaran, dan pengukuran hasil.

Selain itu, Ardianto (2011) lebih lanjut menjelaskan proses dan aspek manajemen dari Dominick (2002:258) yang terdiri atas Information gathering, planning, communication, dan evaluation. Konsep lainnya yaitu ATLU (Asking, Telling, Listening, dan Understanding) dan konsep PIE (Perencanaan, Implementasi, dan Evaluasi) yang tepat sasaran, tepat guna, efektif, efisien dan sesuai target kegiatan Humas yang dicanangkan. 


\section{SIMPULAN}

Simpulan dari penelitian ini bahwa aparat pemerintah Kabupaten Pangandaran sudah mempersepsi atau menafsirkan dengan baik tentang kualifikasi profesi humas dilihat dari aspek ability to communicate, ability to organize, ability to get on with people, serta imagination. Akan tetapi terhadap aspek personel integrity masih ada yang tidak sependapat tentang profesi humas harus latar belakang pendidikan humas/komunikasi dan harus perempuan.

Sebagai saran, masih perlu upaya dari para ahli PR/Humas untuk mengedukasi orang awam tentang kualifikasi profesi humas, karena dengan pengetahuan yang mereka miliki akan mempengaruhi cara mereka menghargai profesi humas, sehingga nanti dalam penempatan atau mengangkat orang/petugas humas akan mempertimbangkan dan menyesuaikan dengan kualifikasi profesi humas (right man on the right place).

\section{DAFTAR PUSTAKA}

Abidin, Yusuf Zainal.(2016).Komunikasi Pemerintahan, Filosofi, Konsep dan aplikasi. Bandung: Pustaka Setia Bandung.

Anggoro, M. Linggar.(2000).Teori dan Profesi Kehumasan serta Aplikasinya di Indonesia. Jakarta: Bumi Aksara.

Ardianto, Elvinaro.(2011).Handbook of Public Relations, Pengantar Komprehensif. Bandung: Simbiosa Rekatama Media.

BPP Perhumas, 2004, Baik, Ridwan Nyak.,et al.(editor).(2004).Koalisi Dominan Refleksi Kritis atas Peran dan Fungsi Public Relations dalam Manajemen. Jakarta: BPP Perhumas.

Beard, Mike.(2004).Seri Praktik PR Manajemen Departemen Public Relatios.Edisi Kedua. Jakarta: Erlangga.

Kriyantono, Rachmat.(2007).Teknik Praktis Riset Komunikasi.Jakarta:Kencana Prenada Media Grup.

Laksamana, Agung. (2010).Internal Public Relations.Jakarta: Republika.

Mulyana, Deddy.(2013).Komunikasi suatu Pengantar.Bandung:PT. Remaja Rosdakarya.

Pace, R. Wayne., Faules, Don F.(1998). Komunikasi Organisasi Strategi Meningkatkan Kinerja Perusahaan. Bandung: PT Remaja Rosdakarya.

Rivai, Veithzal.(2003).Kepemimpinan dan Perilaku Organsasi.Jakarta:PT RajaGrafindo Persada.

Saleh, Akh. Muwafik.(2010).Public Service Communication, Praktik komunikasi dalam Pelayanan Publik. Malang: UMM Press. 
Soemirat, Soleh., dan Ardianto, Elvinaro.,(2002).Dasar-dasar Public Relations. Bandung. PT Remaja Rosdakarya.

Tondowidjojo, John.(2002).Dasar dan Arah Public Relations. Jakarta: Grasindo. 